\title{
SURGICAL APPROACH OF INFECTED MESH WITH ENTERO-ATMOSPHERIC FISTULA - A CASE PRESENTATION
}

\author{
Daniel I. MIHALACHE ${ }^{1}$, Bogdan SOCEA ${ }^{2,3}$, Alexandru C. SMARANDA ${ }^{2,3}$, Anca A. NICA ${ }^{2,3}$, \\ Alexandru C. CARAP ${ }^{2,3}$, Ovidiu G. BRATU ${ }^{3,4}$, Ana Maria A. STANESCU ${ }^{3}$, Florin GROSEANU ${ }^{3,5}$, \\ Mihai C.T. DIMITRIU ${ }^{3,6}$, Vlad D. CONSTANTIN ${ }^{2,3}$ \\ ${ }^{1}$ Surgical Department, County Emergency Hospital, Ploiesti, Romania \\ 2 Emergency Clinical Hospital „Sf. Pantelimon“, General Surgery Clinic, Bucharest, Romania \\ 3 „Carol Davila“ University of Medicine and Pharmacy, Bucharest, Romania \\ ${ }^{4}$ Emergency University Central Military Hospital, Department of Urology, Bucharest, Romania \\ ${ }^{5}$ Emergency Clinical Hospital „Sf. Pantelimon“, Orthopedics and Traumatology Clinic, Bucharest, Romania \\ ${ }^{6}$ Emergency Clinical Hospital „Sf. Pantelimon“, Obstetrics and Gynaecology Clinic, Bucharest, Romania
}

Received 29 June 2019, Accepted 02 August 2019

https://doi.org/10.31688/ABMU.2019.54.3.29

\section{Abstract}

Introduction. Mesh reinforcement is generally considered the standard of care in hernia repair. Infection is a common complication following hernia repair. Infection of the mesh is a complex problem. Knowledge of new treatment strategies is necessary for surgeons performing abdominal wall reconstruction.

Case presentation. We present the case of a 68-year-old woman, who presented with a non-traumatic entero-atmospheric fistula at the site of the hernia repair, which had been done 2 years previously through the implantation of a dual mesh. The fistula has appeared one year previously. The treatment consisted in a complete removal of the infected mesh and segmentary enterectomy. The abdominal wall was repaired through a tissular procedure and the skin was

\section{Résumé}

Approche chirurgicale de l'infection à prothèses présentation de cas

Introduction. Le renforcement des prothèses est généralement considéré comme la norme de soins dans la réparation des hernies. L'infection est une complication fréquente après la réparation d'une hernie. L'infection de la prothèse est un problème complexe. La connaissance de nouvelles stratégies de traitement est nécessaire pour les chirurgiens pratiquant la reconstruction de la paroi abdominale.

Rapport du cas. Nous présentons le cas d'une femme de 68 ans avec une fistule entéro-atmosphérique non traumatique sur le site de la réparation de la hernie qui avait été pratiquée deux ans auparavant par 
left to close per secundam. The postoperative outcome was favorable.

Conclusions. Following excision of infected mesh, multi-staged abdominal wall reconstruction can be considered. Biologic or biosynthetic mesh is recommended when repairing incisional hernias following excision of infected mesh and likely represent the patient's best chance for a definitive hernia repair. Negative pressure wound therapy closure should be considered in higher-risk patients. Mesh infection is a complex complication that is commonly encountered by surgeons performing hernia repair. Prevention through patient optimization should be performed whenever appropriate. However, when patients develop a mesh infection, most of them will require a complete mesh excision and recurrent hernia repair.

Keywords: mesh, infection, abdominal, hernia, repair.

INTRODUCTION

Anterior abdominal repair is one of the most common surgeries performed worldwide with an increasing number of $1 \%-2 \%$ yearly ${ }^{1,2}$. Meshes have clearly demonstrated beneficial option of repairing hernias better than tissue repair alone due to the reinforcement of native tissue and the lateralization of force across the abdominal wall ${ }^{3}$. Meshes have also been successfully used in unusual locations of parietal defects like Spieghelian hernia ${ }^{4}$. Mesh reinforcement is considered the standard method of hernial repair. Unfortunately, the implantation of foreign bodies can be associated with postoperative complications including seroma, mesh migration, mesh infection, or mesh fistula ${ }^{5,6}$. Mesh infection can occur between $1 \%$ and $8 \%$ of anterior hernia repair and remains a challenging postoperative complication ${ }^{7-9}$. Mesh infections are the third leading cause of reintervention following hernial repair and can result in significant patient morbidity, prolonged hospital stay, and increased costs $\mathrm{s}^{8,10,11}$. l'implantation d'une prothèse à double faces. La fistule était apparue depuis un an. Le traitement consistait en l'élimination complète de la prothèse infectée et l'entérectomie segmentaire. La paroi abdominale a été réparée par une procédure tissulaire et la peau a été laissée se refermer par seconde. Le résultat postopératoire était favorable.

Conclusions. Après l'excision d'une prothèse infectée, une reconstruction de la paroi abdominale en plusieurs étapes peut être envisagée. Une prothèse biologique ou biosynthétique est recommandée lors de la réparation d'une hernie incisionnelle après l'excision d'une prothèse infectée et représente probablement la meilleure chance du patient pour une réparation définitive de la hernie. La fermeture du traitement des plaies par pression négative doit être envisagée chez les patients à risque élevé. L'infection par les prothèses est une complication complexe fréquemment rencontrée par les chirurgiens pratiquant la réparation d'une hernie. La prévention par l'optimisation du patient doit être effectuée chaque fois que cela est appropriée. Cependant, lorsque les patients développent une infection à prothèses, la plupart nécessiteront une excision complète et une réparation récurrente de la hernie.

Mots-clés: prothèses, infection, abdominale, hernie, réparation.

\section{Case presentation}

We present the case of a 68-year-old woman, known with arterial hypertension, obesity and a ventral hernia repair. She presented to our clinic for chronic abdominal pain, a non-traumatic entero-tegumentary fistula with necrotic and serous-intestinal secretion, located at the site of the hernia repair, which has been done 2 years previously through the implantation of a dual mesh. The patient accused that the fistula has appeared one year before, but she did not seek medical consultation.

The patient's clinical examination revealed only abdominal pain at the site of the fistula, when mobilized, with the excretion of a serous-necrotic substance on palpation. We could palpate solid tissue underneath the skin and a small cellulitic perilesional area could be observed. The patient also accused prolonged and intermittent fever. The chest radiography was normal. White cell blood count showed leukocytosis, which was the only abnormal blood test.

After the clinical and paraclinical examination, we decided to perform surgery for the excision of the mesh and the repair of the abdominal wall. The area of infection was represented by the infection of the scar tissue itself, formed around the mesh. This 


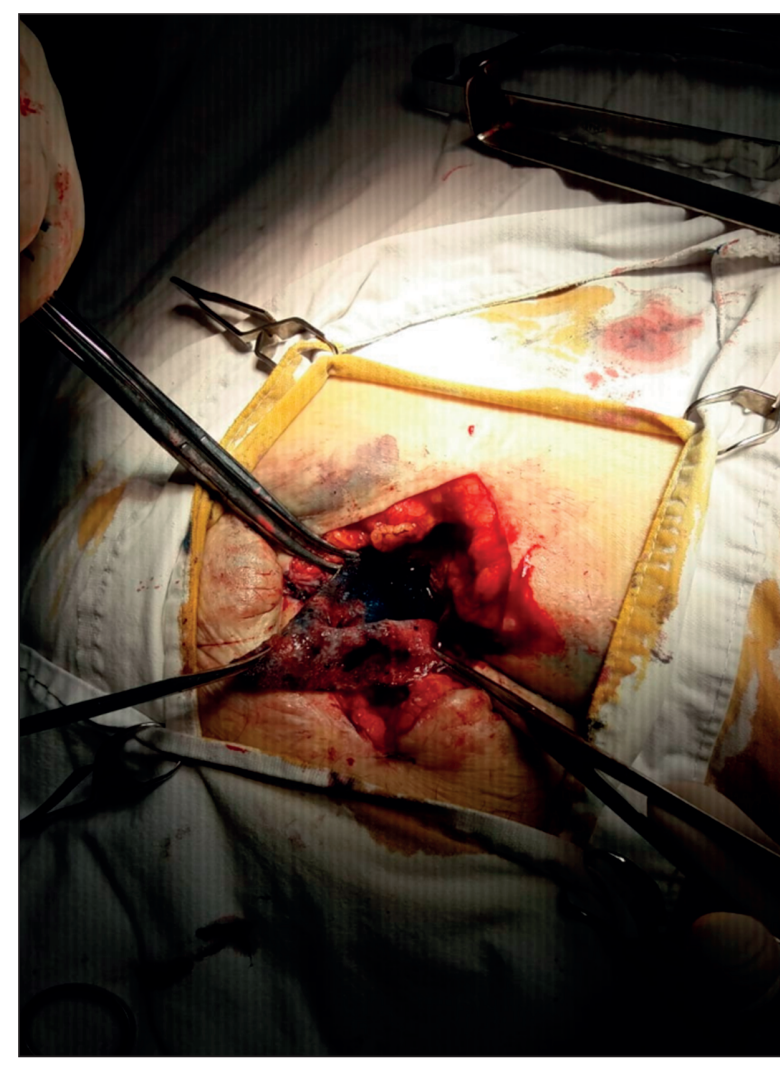

Fig.1. Incision made to extract the mesh. Perilesional hematoma is observed.

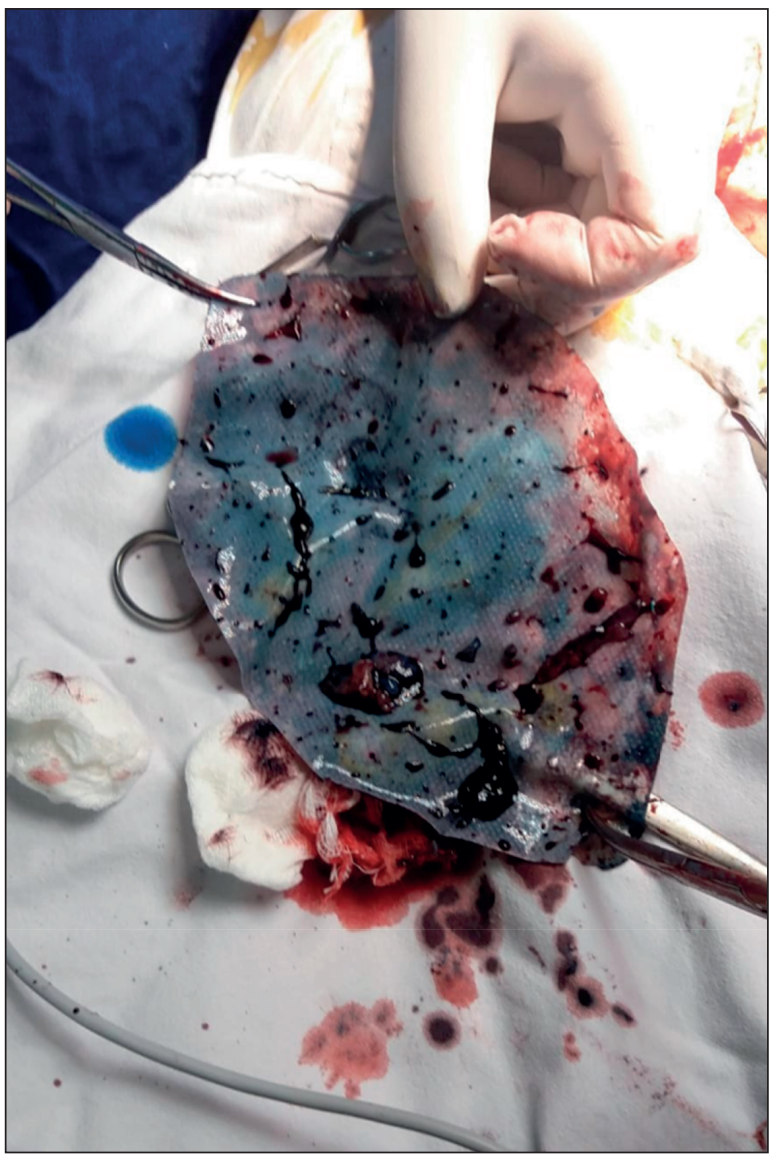

Fig. 3. The excision of the whole alloplastic material.

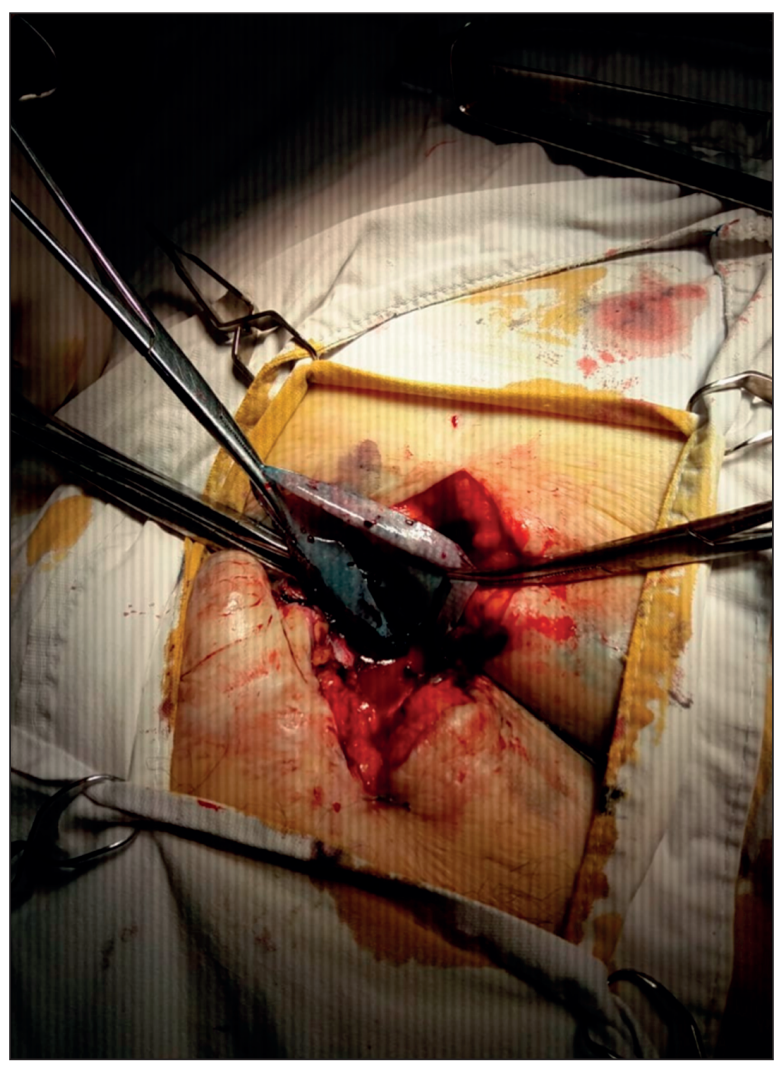

Fig. 2. Removal of the necrotic tissue along with the mesh.

continued to suppurate for a year and create fistula trajectory to the skin, eliminating necrotic tissue, serous-intestinal liquid.

A small incision was made, to excise the mesh and the trajectory of the fistula (Fig.1, 2). At the enteric fistula ending, we performed a segmented enterectomy, followed by a latero-lateral anastomosis. The whole mesh had to be removed (Fig. 3). The area was cleaned through necrotomy and chemical lavage. The abdominal wall was repaired through a suture and the skin was left to close per secundam.

The patient had an uneventful postoperative stay, with the daily cleaning of the open incision. At the 2 weeks visit, we proposed the secondary closure of the skin, but the patient refused, so we decided to let it close by itself. The postoperative outcome was favorable, with no relapse of enteric fistula.

\section{Suture versus mesh repair}

Most authors agree that the basic operative goals in patients with mesh infection include infection control, restoration of gastrointestinal continuity if necessary, and stable hernia repair. Multi-staged hernia repair is an option, with excision of the infected mesh and suture repair of the fascial defect performed during the first operation, followed by a definitive repair 
with a mesh at a planned reintervention, once the infection has cleared and healing has been completed. The excision of infected mesh with suture repair of the fascia is considered a multi-stage repair, due to the almost universal hernial recurrence after the first operation. Even in clean cases, with small defects, suture repair results in a very high rate of hernial recurrence ${ }^{3}$. Single-staged repairs with synthetic mesh are generally considered inappropriate due to the very high risk of re-infection, regardless of mesh type ${ }^{12}$. The Ventral Hernia Working Group does not recommend the use of permanent mesh in infected fields $s^{7,13}$.

Polypropylene mesh is a better solution for hernia repair than polyester. Heavy weight large pores structure seems to be best integrated in human tissues. Polypropylene mesh provides better repair (lower recurrence rate and lower mesh shrinkage rate in time). All recurrences appeared in the first two years after primary repair ${ }^{14-16}$.

In the case of alloplastic repair, the tolerance of the organism towards the non-biologic material should be taken into consideration. Three types of meshes made of different synthetic materials were characterized by mesh density, pore size, pore shape, material composition and mechanical properties ${ }^{17-19}$, which should always be taken into consideration regarding the tissue's tolerance, site and size of the hernia, in order to minimize the post-operative complications ${ }^{20}$.

\section{Conclusions}

Despite advances in surgical technique and materials, mesh infection remains one of the most difficult postoperative complications following hernial repair. Without guidelines and robust databases with long-term follow-up of mesh, management of infections remains complicated and is usually guided by the surgeons' personal experience ${ }^{1}$. Minimally invasive techniques, as well as following the general principles of perforator-sparing skin and subcutaneous tissue mobilization and incisional wound management, will decrease the risks of surgical-site complications and thereby mesh infections ${ }^{14,21}$.

For open surgery, mesh infections are a real concern, despite the correct choice of prosthetic material, the rigorous sterility and proper antibiotic coverage. Using the correct mesh and the wires for a proper suture will assure a low rate of mesh-related complication. The solutions for mesh infection are the complete removal of the prosthetic material, a complete debridement of the region and a correct administration of systemic antibiotics ${ }^{17,18}$.

Consideration should be given to abdominal wall reinforcement with non-synthetic mesh and delayed primary wound closure, as we have done in our case. The particularity of this case consists in developing a late entero-atmospheric fistula after a ventral hernia repair procedure using a dual mesh prosthesis. Management of patients with mesh infection is complex and must benefit from a multidisciplinary consult. Long-term follow-up of patients will elucidate the value of these interventions and facilitate future development of guidelines for management ${ }^{1}$.

\section{Compliance with Ethics Requirements:}

„The authors declare no conflict of interest regarding this article"

"The authors declare that all the procedures and experiments of this study respect the ethical standards in the Helsinki Declaration of 1975, as revised in 2008(5), as well as the national law. Informed consent was obtained from the patient included in the study"

"No funding for this study"

\section{References}

1. Arnold MR, Kao AM, Gbozah KK, Heniford B T, Augenstein VA. Optimal management of mesh infection: Evidence and treatment options. Int J Abdom Wall Hernia Surg 2018;1:42-9.

2. Poulose BK, Shelton J, Phillips S, et al. Epidemiology and cost of ventral hernia repair: Making the case for hernia research. Hernia 2012;16:179-83.

3. Usher FC, Ochsner J, Tuttle LL Jr. Use of Marlex mesh in the repair of incisional hernias. Am Surg 1958;24:969-74.

4. Socea B, Smaranda AC, Nica AA, et al. Spiegel hernia - case presentation. Arch Balk Med Union 2018;53(1):152-4.

5. Burger JW, Luijendijk RW, Hop WC, et al. Long-term follow-up of a randomized controlled trial of suture versus mesh repair of incisional hernia. Ann Surg 2004;240:578-83.

6. Mavros MN, Athanasiou S, Alexiou VG, et al. Risk factors for mesh-related infections after hernia repair surgery: A meta-analysis of cohort studies. World J Surg 2011;35:2389-98.

7. Socea B, Carap A, Bratu OG, et al. The role of the composite and biologic meshes in the trocar site hernia repair following laparoscopic surgery. Revista de Materiale Plastice 2018;55(2):146-148.

8. Carlson MA, Frantzides CT, Shostrom VK, Laguna LE. Minimally invasive ventral herniorrhaphy: An analysis of 6,266 published cases. Hernia 2008;12:9-22.

9. Baleanu V, Georgescu I, Davitoiu D, Manda L, Socea B, Tenea-Cojan TS. Incisional hernia complications after using polypropylene mesh - case report. Research and Science Today 2018;Suppl. 1(15):126-133.

10. Hawn MT, Gray SH, Snyder CW, et al. Predictors of mesh explantation after incisional hernia repair. Am J Surg 2011;202:28-33.

11. Constantin V, Carap A, Bobic S, Albu M, Nica E, Socea B. Traumatic abdominal wall hernia associated with small bowel injury - case report. Indian J Surg 2015;77(Suppl 1):174-7.

12. Majumder A, Petro CC, Liu L, Fayezizadeh M, Novitsky YW. Development of a novel murine model for treatment of infected mesh scenarios. Surg Endosc 2017;31:922-7. 
13. Constantin VD, Socea B, Nica E, et al. A comparison between two types of textile meshes and the intra-abdominal pressure values after Rives-Stoppa incisional hernia repair. Industria Textila 2015; 66(2): 80-84.

14. Clarke JM. Incisional hernia repair by fascial component separation: results in 128 cases and evolution of technique. Am J Surg 2010;200:2-8

15. Socea B, Socea LI, Bratu OG, et al. Recurrence rates and mesh shrinkage after polypropylene vs. polyester mesh herniarepair in complicated hernias. Revista de Materiale Plastice 2018;55(1):79-81.

16. Sanchez VM, Abi-Haidar YE, Itani KM. Mesh infection in ventral incisional hernia repair: Incidence, contributing factors, and treatment. Surg Infect (Larchmt) 2011;12:205-10.

17. Finan KR, Vick CC, Kiefe CI, Neumayer L, Hawn MT. Predictors of wound infection in ventral hernia repair. Am J Surg 2005;190:676-81.
18. Trandafir A, Vasile D, Davitoiu D, et al. The new self-gripping mesh and it's benefits in inguinal hernia repair - review of the literature. Research and Science Today 2018; 1(15): 132-139.

19. Constantin VD, Carap A, Socea B, Ficai A, Albu MG, Paunica-Panea $G$. The influence of synthetic material meshes on the surgical repair of abdominal wall defects. Romanian Journal of Materials 2015; 45(3): 290-297.

20. Socea B, Diaconu C, Bratu OG, et al. Postoperative outcome of a giant incisional hernia resolved by anterior component separation technique. Romanian Journal of Medical Practice 2018;XIII (4):268-70

21. Socea B, Nica AA, Bratu O, et al. Incidental finding of a sigmoid intussusception associated with rectal prolapse - a case report. Arch Balk Med Union. 2018;53(1):143-146. 